\title{
The economic impact of the French language
}

\author{
Violeta Mihaela DINCĂ \\ The Bucharest University of Economics, Bucharest, Romania \\ violetamihaeladinca@yahoo.fr \\ Anca BOGDAN \\ The Bucharest University of Economics, Bucharest, Romania \\ anca.bogdan@fabiz.ase.ro \\ Monica Z0TTU-Z \\ Bucharest University of Economics, Bucharest, Romania \\ monica.zottu@yahoo.com \\ Teodora FLORICEL \\ Bucharest University of Economics, Bucharest, Romania \\ teo89_teo@yahoo.com
}

\begin{abstract}
Thanks to the French language, 77 member and observer States and governments of the International Organization of La Francophonie of all continents, with levels of development at the two extremes of the wealth scale, can maintain a regular dialogue. These states where French is an official language, often alongside other languages have a significant impact on the global economy, particularly in cultural sectors. Several studies revealed that speaking French is a professional asset and that, the mastery of many languages, including one for international communication such as French, is a decisive asset in the international competition and the globalized economies. In the same time the intensity of trade in goods and capital between the countries which share the French language as an official language allow the hypothesis of a "linguistic preference" as one of the components favorable to the economic relations between the territories. The scope of this paper is to investigate the current place of the French language in the field of business or finance, its economic weight in the cultural sector and the current need to master French to be competitive on the global labor market. The results have the mission to show the growing importance of the francophone economic space and the necessity of a bigger Romanian implication within its projects and initiatives. The contribution brought by the paper to the field of Francophone studies is significant especially for the Romanian academic environment since less attention has been given in the last decade to the French language and its inputs for the economy.
\end{abstract}

Keywords: International Organization of La Francophonie, the French language, economic input, cultural sector, francophone business environment.

\section{Introduction}

Confronted with many different economic, climatic, ecological, commercial and geostrategic contexts, the IOF member and observer states consult each other on major economic issues like financial regulation (Summit of the Francophonie Montreux, 2010), sustainable development (preparation for the Rio + 20 Summit), green growth, innovative financing for development and food security of Francophone developing countries (G20, alongside the Commonwealth). 
Even with these difficulties the French language, which links more than 220 million people from all four corners of the globe, is a formidable economic trump card for the 57 state members of the International Organization of La Francophonie (IOF). At the XVIth and last Summit of the IOF it was underlined the need to transform the Francophonie organization into a veritable economic community.

PICBE | 325

\section{Literature review}

Vigouroux (2013) developed a study in which she explores different facets of la Francophonie, both as an international institution dedicated to the defense of French and as a group of people who speak or are united by French. She remarks that having been highly ideological since its beginnings and its association with France's colonial history, the very idea of la Francophonie has aroused passionate debates both within and without. Although it was officially launched as a cultural community seeking to develop economic partnership, it has evolved into a political organization promoting human rights and democracy and defending cultural diversity against Anglo-American hegemony (Vigouroux, 2013).

A study performed by OIF in 2016 reveals that IOF member and observer countries represented $14 \%$ of world gross national income, $14 \%$ of the world's population, $20 \%$ of world merchandise trade and $11 \%$ of world trade in cultural products and services (IMF, 2016; UNATCD, 2016).

The studies of François Grin on the economic weight of languages has dealt with the issues of the French language for 29 countries where French is the official or co-official language, plus some other 20 countries where French has retained an important place in the social, cultural and educational life. These researches allow us to determine that all of those "francophone" countries carry from economic point of view $2.87 \%$ their demographic weight. This result corresponds to the coefficient obtained through the division of the sum of economic indicators (GNI, GDP) of the 49 countries to the sum of their demographic indicators when compared to global economic and demographic indicators (Grin et al., 2010).

It should also be noted that French ranks second in the Calvet barometer of the world's languages, which evaluates the weight of languages taking into consideration ten different factors that have the same weighting. Among these factors, we can mention in particular the number of speakers, the human development index, the Internet penetration rate and the translations that take French sometimes as source language, sometimes as target language (Portalingua, 2011).

The IOF countries have been divided into three categories represented by categories of the Gross National Income in table 1 (IOF, 2016):

1. Countries with French as an official or co-official language: Belgium, Benin, Burkina Faso, Burundi, Cameroon, Canada (including Quebec and New Brunswick), Central African Republic, Comoros, Congo, Congo DRC, Ivory Coast, Djibouti, France, Gabon, Guinea, Equatorial Guinea, Haiti, Luxembourg, Madagascar, Mali, Niger, Rwanda, Senegal, Seychelles, Switzerland, Chad, Togo, Vanuatu.

2. The member countries of "La Francophonie" (including all countries in category 1): Algeria, Albania, Armenia, Bulgaria, Cambodia, Cape Verde, Cyprus, Dominica, Egypt, the Former Yugoslav Republic of Macedonia, Ghana, Greece, Guinea-Bissau, Laos, Lebanon, 
Morocco, Mauritius, Mauritania, Moldova, Romania, Saint Lucia, Sao Tome and Principe, Tunisia, Vietnam.

3. The member and observer countries of "La Francophonie" (including all the category 2): Austria, Bosnia and Herzegovina, Croatia, Dominican Republic, United Arab Emirates, Estonia, Georgia, Hungary, Latvia, Lithuania, Montenegro, Mozambique, Poland, Serbia, Slovakia, Slovenia, Czech Republic, Thailand, Ukraine.

PICBE | 326

Table 1 Total GNI of countries within "La Francophonie"

\begin{tabular}{|l|c|l|l|l|}
\hline Categories & $\begin{array}{l}\text { Total GNI } \\
\text { in billions } \\
\text { of }\end{array}$ & $\begin{array}{l}\text { Global } \\
\text { Gollars }\end{array}$ & $\begin{array}{l}\text { GNP } \\
\text { share } \\
\text { (purchasing power } \\
\text { parity) in billions of }\end{array}$ & $\begin{array}{l}\text { GNP } \\
\text { share } \\
\text { US dollars }\end{array}$ \\
\hline $\begin{array}{l}\text { Countries with French as official } \\
\text { language or co-official language }\end{array}$ & 5410,4 & $8,6 \%$ & 4703,6 & $6,2 \%$ \\
\hline Member countries of La Francophonie & 6675,4 & $10,6 \%$ & 6984,6 & $9,2 \%$ \\
\hline $\begin{array}{l}\text { Member and Observer countries of } \\
\text { Francophonie }\end{array}$ & 8920,1 & $14,2 \%$ & 10010 & $13,1 \%$ \\
\hline Global value & 62959,5 & $100 \%$ & 76253,6 & $100 \%$ \\
\hline
\end{tabular}

Source: Authors' own adaptation with data acquired from the World Bank 2017.

The weight of countries having French as an official or co-official language in the overall economy of culture with a world value 2,623.6 billion \$US for 2016. Also for 2016, the global weight of Francophones in terms of cultural exchanges is twice their demographic weight (11\% of cultural exchanges for $5.5 \%$ of the world population). The weight of countries having French as an official or co-official language in the audiovisual content and associated services market for 2016 was $14,43 \%$, while the weight within the global imports of audiovisual content and associated services was of $22.29 \%$ (UNCTAD, 2016).

When Quebec is concerned, the entries at French films screenings within cinemas generated revenues from ticketing of the equivalent of US \$ 129.0 million in 2016, or 72\% of total revenues from cinema tickets in Quebec for 2016. This means that 72\% of the people who watched movies at the cinema in 2016 saw French films. In 2015-2016, the 37 feature films in French produced in Quebec for the rooms had a total production cost of C \$ 169.0 million (US $\$ 170.9$ million). Entrances to paid shows of French-language songs generated revenues from ticketing of CA\$ 23.6 million (US \$22.9 million) in 2016. Since 2010 until 2016, recorded music albums in French have always occupied a majority of all Quebec albums sold. The value of sales of digital albums in French for 2016 was C\$ 3.0 million (US \$ 2.8 million), 5 times higher than 2004. For the book market, the proportion of book titles published in French $(8,466)$ represented $88.5 \%$ of all titles published in Quebec for 2016. In the same time, the television industry of Quebec generated a net profit of $\mathrm{C} \$$ 145.7 million (US \$ 141.5 million) (Institute de la Statistique du Quebec, 2016). 
For France, the culture sector generated more than half a million jobs in France in 2016. 272 films were produced in 2016 with financial support from the public sector compared with 203 in 2015 and 182 in 2014. Of these 272 films, 207 are so-called "initiative French" (CNC, 2016).

Total investment in French initiative films amounted to US \$ 1.4 billion in 2016. In 2016, the market shares of French films amounted to $35.5 \%$ France $(73.4$ million admissions), $12.7 \%$ in Belgium and $7.8 \%$ in Switzerland. When it comes to the music industry in France, nearly 20\% of the music titles broadcasted on radio stations in 2016 were Francophone titles. In 2016, 79,300 book titles were published and 632 million copies were produced by 350 publishing houses. The turnover of the publishing market, which includes revenues from sales of books and rights sales, amounted to US \$ 3.6 billion for 2016. Regarding the theatre market there were about 5.3 million theater admissions in France for the 2015-2016 season (theaters and national scenes of France and private theaters of Paris). The revenues of French national theaters and private theaters of Paris, in 2016, amounted to US \$ 166.4 million (Observatoire européen de l'audiovisuel, 2016).

For Burkina Faso the number of jobs generated by the culture sector, which includes publishing, music, audio-visual and cultural events, is estimated at 1,271 jobs fulltime for 2016. Revenues in the culture sector are estimated at US \$ 6.8 million. It is estimated that the audiovisual market generated at least 778 jobs and US \$ 1.4 million for 2016 (IOF, 2016).

For the Ivory Coast, the number of full-time jobs generated by the cultural industries of Côte d'Ivoire is estimated at around 3,655 in 2016 while companies operating in the cultural sector are microenterprises. Their turnover was between $\$ 8,400$ and $\$ 550,000$ US in 2016. The book and publishing market has estimated to have generated 1,300 jobs and US \$57.6 million in 2016 (IOF, 2016).

For Senegal, the cultural industries generate around 2455 jobs and 27,3 million US. In 2016, the value of exports of books has risen at 2,5 M\$ US. This amount knows a continuous rise ever since 2010 with an average growth of $26 \%$. Senegal is therefore the greatest exporting country of books of the West African Economic and Monetary Union (UEMOA). The turnover of the audiovisual sector is evaluated at 32,8 M\$ US. A third of this turnover comes from the TV production. There are 7 television channels in Senegal, one of them being public, and 27 private radio stations. The market of the musical production is very dynamic, has a lot of potential, witnessed by the international broadcasting of the Senegal music. Officially, it generates around 660 jobs and 1 M\$ US, even though it is known that the part of pirated works that circulate on the market is important. As a matter of fact, the market is in a very big part composed of microenterprises (81\%) (IOF, 2016).

\section{Methodology}

This paper is the result of various concurrent studies, in particular: four institutional assessments from the Organisation internationale de la Francophonie (OIF), one study conducted by the University Agency of La Francophonie, one study elaborated by the world Bank together with the IMF and one research which belongs to the United Nations Conference on Trade and Development. 
Each of these institutions documents were consulted in order to: assess the relevance, efficiency, and effectiveness of the French language on the labor market, to assess its importance within the business environment in different countries belonging to La Francophonie, to identify which are the most notable academic institutions which provide studies in the French language and what investments are being performed at national (from each country's national budget) and at international level (supported by the institutions mentioned before) to surpass the organizational challenges that the French language encounters in the economic milieu.

The compilation of documents reviewed for this paper includes various types of researches which can be categorized as: information documents about the institution, program frameworks, activity reports, colloquium proceedings, minutes, financial documents, declarations and action plans, working documents of each institution different bodies, references, discussion papers, and policy papers etc.

One observation could be made that the information required to conduct this jointevaluation-especially the financial data-varied considerably in quantity and availability and some data were difficult to find, because they were buried under complex data management systems.

\section{Results and discussions}

\section{The competitive edge of mastering the French language}

Thanks to the Francophone Employment Forums organized in Bucharest or Hanoi at the initiative of the Francophone University Association (AUF-Agence universitaire de la Francophonie), several hundred Francophone young people can apply every year to companies gathered for the occasion.

In Lebanon, a survey of 91 companies (53\% with majority Lebanese capital) developed in 2014, revealed that, for $43 \%$ of them, more than half of the employees are Francophone and that $49 \%$ of recruiters ask the candidate "always" or "often" to speak French (IOF, 2015).

In Québec in 2016, 85.2\% of businesses with 50 or more employees $(5,211$ businesses) have generalized the use of the French language. More than ever, mastering the French language is an essential condition for being hired and promoted within the labor market in Quebec (Office québécois de la langue française, 2016).

Surveys show that for French exporting companies, speaking French is a "strong or crucial" competitive advantage in front of Francophone clients. The rates of increase of the working income of a person who is perfectly fluent in the French language in Germanspeaking and Italian-speaking Switzerland were situated between $+15 \%$ and $+26 \%$. In Abidjan, Bamako, Dakar, Douala, Kinshasa and Libreville, between $66 \%$ and $98 \%$ of respondents interviewed within the surveys developed by TNS-Sofres believe that French is "important" or "indispensable" to graduate from higher education, to carry out administrative procedures, to get information from the media, to get a job and "make a difference". In Brussels, French is essential in a context of official bilingualism, presence of international companies, proximity to Francophone markets and predominance of the tertiary sector. More than $90 \%$ of Belgian companies use French in the workplace (Grin, 2013). 


\section{French as a professional language}

\section{In India}

According to information collected by the French Embassy in India in 2015, 70\% of learners within the French Alliances have managed to "build their curriculum vitae" by learning French. The decision to learn French is most often taken in a personal capacity, and not at the requests of companies, except in Bombay, where employees are encouraged to acquire French skills but without providing financial support.

On average, $20 \%$ of French learners wish to eventually integrate within a Frenchspeaking company in India or pursue studies in France. In 2015, according to Ernst and Young, France was the second largest investor in India, after the United States, with very large projects (Michelin, Renault, Dassault, L'Oréal for example).

Among those who learn French for professional reasons, 75\% of those registered in the French Alliances of Gujarat and Punjab have plans to emigrate to Quebec. Among the business courses given by the French Alliances, 35\% are in Francophone companies (IOF, 2015).

\section{In Indonesia}

In $2015,19,7 \%$ of the registrants at the French Institute and at the French Alliances 1357 people) learned French for professional reasons. In $75 \%$ of the cases, they had professional plans to work in France. This number represents a small increase, compared to 2014 (18.2\%).

From 1357 of the registrants, 22\% learned French at the request of their company. Among these companies, $20 \%$ belonged to the private sector and $2 \%$ to the public sector. Therefore, the part of the requests coming from individuals (natural persons, not companies or legal persons) was therefore 78\%. Among French courses in business, $86 \%$ were given in the foreign companies and 14\%, in the francophone enterprises (IOF, 2015).

\section{In Tanzania}

On average, $26 \%$ of the people enrolled at the French Alliances of Dar es salaam and Arusha (479 people) learned French for professional reasons in 2016. Of these people, 55\% work in a private company and $45 \%$ in a public one.

Among these registrants, 34\% chose to learn French for working with other African countries, only 6\% for working with France and 60\% for working with Quebec, or with other francophone zones. Many of the learners from Arusha take French classes to work with Switzerland.

Of all these French courses held in private enterprises, 94\% are given in nonfrancophone enterprises and 6\% in francophone companies. Many learners of the French Alliance of Arusha are from international organizations or from non-francophone enterprises with an important number of francophone clients (IOF, 2015).

\section{In China}

At the French Alliances of China, the percentage of the registrants who learn French for professional reasons varies enormously: between $8 \%$ and 36\%. The most significant 
sample is the one from the French Alliance of Canton, where this percentage in 2016 rises to $35 \%$.

On average, between $0 \%$ and $2 \%$ of the people enrolled learn French at the request of their company. The French Alliances of Pekin (10\%), Canton (5\%) and Wuhan (5\%) concentrate the most of this type of requests.

Between $20 \%$ and $22 \%$ of the registrants at the French Alliances of China learn

PICBE | 330 French for professional reasons, in order to work with Quebec and 4\% to work with France (IOF, 2015).

\section{Doing business in French}

On average, $26 \%$ of the people enrolled at the French Alliances of Dar es salaam and Arusha (479 people) learned French for professional reasons in 2016. Of these people, 55\% work in a private company and $45 \%$ in a public one.

The research of the Association "Actions for promoting the French language for business reasons (Action pour promouvoir le francais des affaires ou APFA), questioned in 2015 the French companies located abroad (group A in the countries where French is a very used language, group B in the countries where the most used language is English and group $C$ in the countries where the most used language is neither French, nor English). The following conclusions were drawn.

In $36 \%$ of the cases, the French companies use the French language abroad ( $80 \%$ for group A and 8\% for group B), especially when they are in a position of purchasing. This fact is particularly true for the companies of the group $\mathrm{C}$.

Furthermore, half of the French companies studied (52,5\%) use the language of the host country and $41 \%$ write the commercial contracts in French and in the language of the host country (but only 20\% pour the group B). The utilization of the language of the host country is considered as a favorable element for the sustainability of the commercial actions for $89 \%$ of enterprises.

Finally, in $42 \%$ of countries of this sample, there are education programs for the French language for business purposes (66\% for group A and 22\% for group B), with an average of 3300 students (IOF, 2016).

\section{Some francophone initiatives}

The International Francophonie Economic Meetings (IFEM) (2012 and 2016) allow several hundred French speaking economic operators to organize the strengthening of business links between Francophones. They represent the occasion to express the economic interest in the French language as language of entrepreneurship, of legal and tax harmonization, of the intellectual property, of international investments, etc.

For its part, the Francophone Business Forum represents, since 1987, a network grouping companies from member and observer countries of the Francophonie.

The Network of Francophone Professional Associations (NFPA) was born in 2011 with the Charter of francophone professional associations, elaborated under the aegis of the International Organization of the Francophonie (IOF). Grouped within the network, notaries, surveyors, chartered accountants and external auditors, standard and quality experts, engineers and scientists, biomedical technologists, nurses, physiotherapists, 
international civil servants and project management specialists, in particular, will be able to deal jointly with the issues and challenges related to the promotion of the French language in its professional, technical, scientific, economic or financial usages.

The NFPA will contribute to the diffusion at large scale of a tradition, of a culture and of the professional francophone systems which have proved their efficacy and will promote the exchanges and the international cooperation.

PICBE | 331

\section{Acquire a university education in French}

The university agency of the Francophonie (AUF), which counts 784 member institutions in 98 countries, is globally one of the biggest association of universities. It brings together institutions of higher education and research from five continents which use the French as language of teaching and research. AUF in 2016 has provided (AUF, 2016):

- 2856 scholarships awarded to students, teachers and researchers, including 2014 mobility scholarships and 842 local benefits.

- 99 projects of scientific cooperation, supported interuniversity, using 375 higher education and research institutions.

- 92 supervised $\mathrm{PhD}$ students for the francophone horizons project in West Africa, Maghreb and the Indian Ocean.

- 6013 students registered in 85 French university programs of training supported by AUF.

- 246 students trained in the 5 international institutes of the Francophonie (Bulgaria, Haiti, Laos, Mauritius and Vietnam).

- 20213 beneficiaries of the trainings in information and communication technologies proposed by the 44 French language digital campuses.

- 1266 students trained in the 72 open and at distance courses supported by AUF for the 2015-2016 academic year.

- 5946 students and 419 teachers beneficiaries of the upgrade level courses of the French language.

- 8500 copies of the newsletter "The French at the university" broadcasted in 150 countries.

- 19497 primary documents (articles and thesis) broadcasted; 13 published works.

\section{Official development assistance}

The percentage shown in the above graphs suggest that belonging to the Francophonie and the French language as a shared language are the most highlighted factors of solidarity. In particular, Belgium pays $31 \%$ of the amount allocated at the public aid for development, to the countries which have French as official or co-official language. 


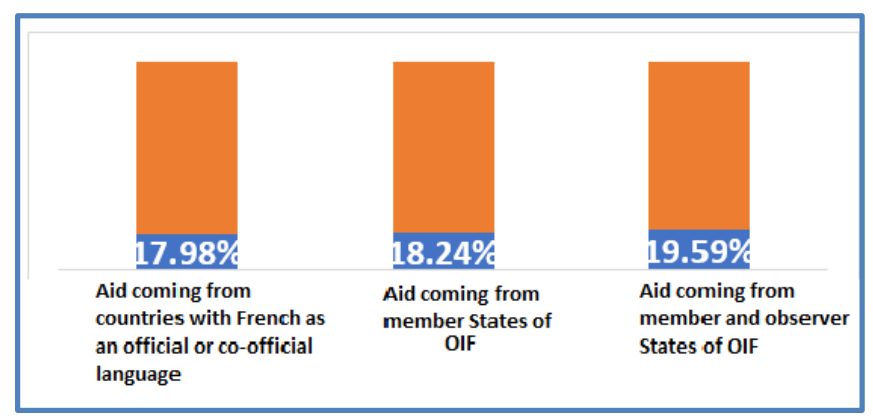

PICBE | 332

Figure 1. Allocation of official development aid to member and observer countries of the IOF (total value: US \$ 33.1 billion)

It pays $37,4 \%$ of the same amount for the member and observer states of La Francophonie. Luxembourg attributes, from its part, 32,2\% of the public aid for development, to the member and observer States of La Francophonie, while France allocates 25,7\% (IMF, 2016).

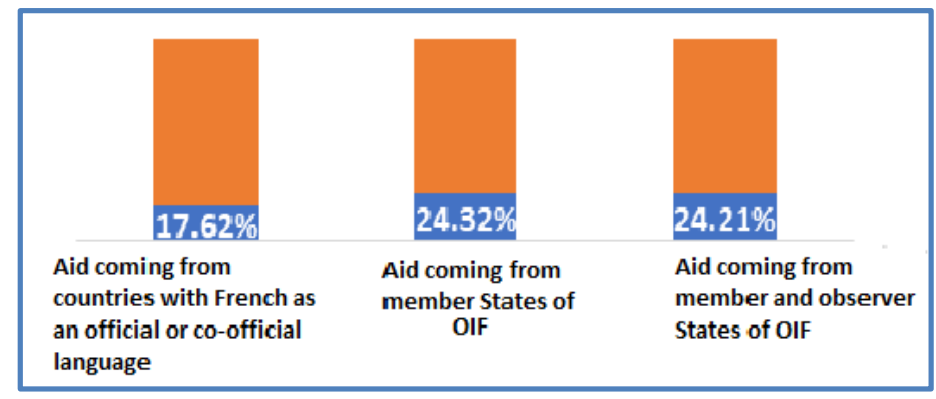

Figure 2. Official development assistance to member countries and observers of the IOF by countries having French as their official or co-official language (total assistance paid: US $\$ 23.8$ billion)

The trade exchanges

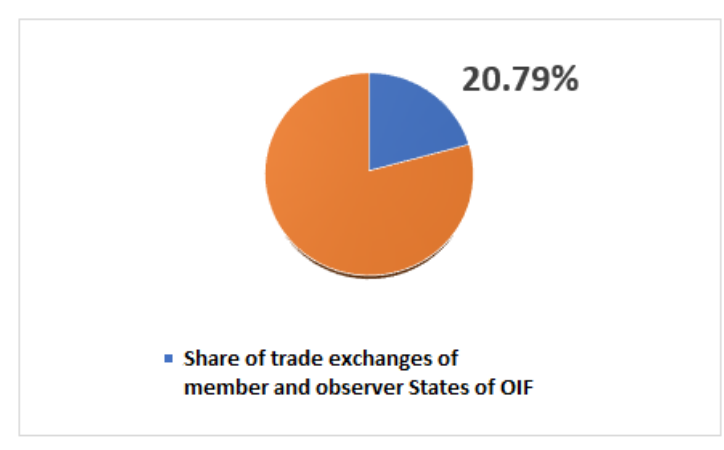

Figure 3. Share of trade exchanges of member and observer countries of IOF within the world trade (total world value: US \$ 30,222.6 billion) 
The trade exchanges between the countries which are members and observers of the Francophonie can be translated mainly in the value of trades with the countries which have French as an official or co-official language: US $\$ 648.3$ billion.

The value of trades with the countries which are members of the Francophonie: US \$ 852.4 billion. The value of trades with the countries which are members and observers of the Francophonie: US \$1498.5 billion (IMF, 2016).

PICBE | 333

We will present the profile for 2015 of three IOF countries that perform a large part of their trade with other member countries of the Francophonie.

\section{Burkina Fasso}

Burkina Faso is a country of IOF which realizes the biggest part of the trades with members of the Francophonie (without the observers) with 55,3\% of the total.

Burkina Faso's main trading partners in the Francophonie are the Ivory Coast, with which the country achieves $20,2 \%$ of its trade, France $(12,7 \%)$, Belgium $(5,3 \%)$ and Ghana $(4,6 \%)$. The main trade partner of the countries outside La Francophonie is China $(6,1 \%)$.

The public aid for development allocated to Burkina Faso by countries members and observers of the Francophonie is of $15,4 \%$ of the total amount (OIF, 2015).

Mali

Mali arrives the third among the countries which realize the biggest part of their trade with other members of the Francophonie with $41,1 \%$ of the total.

The main trade partners of Mali in the Francophonie are Senegal, with which the country realizes $14 \%$ of its trades, France $(9,8 \%)$ and the Ivory Coast $(9,7 \%)$. The main trade partner outside La Francophonie is China $(8,2 \%)$.

The public aid for development attributed to Mali by member and observer countries of La Francophonie is 20,7\% (OIF, 2015).

\section{Tunisia}

Tunisia arrives to the sixth position among the countries which realize the biggest part of their trades with the other members of the Francophonie, 32,6\%.

The main trade partners of Tunisia within La Francophonie are France, with which the country achieves $23,28 \%$ of its trade, and Belgium (2,62\%). Algeria, a non-member of La Francophonie, but marked by a powerful presence of the French language, is also an important trade partner of the country $(2,41 \%)$. The main trade partner outside the Francophonie is Italy $(19,54 \%)$.

The public aid for development attributed to Tunisia by the other member and observer countries of La Francophonie represents 22,5\% (OIF, 2015).

\section{Conclusion}

The highlighted facts presented in this article illustrate briefly the economic impact of the French in different sectors of activity related to the culture, the labor market and the international exchanges.

By encouraging the utilization of the French language in these different activities which are essential to the economic life, the member states of La Francophonie will assure 
the influence of the French as a major language of international communication. Far from being an anecdotal decision, it is one which symbolizes a new ambition for these countries: to transform the Francophonie organization into a veritable economic community.

For a long time now, the geographical breaking-up of francophone areas and the huge socio-economic disparities between their members have been considered insurmountable obstacles to developing long-lasting and competitive economic trade. But the nature of the globalized and, at least in part, dematerialized world economy has completely changed things and la Francophonie has more obstacles to surpass toward the creation of an economic community of French-speaking countries that could position itself in the medium-term towards economic areas of great potential with a strong linguistic dimension.

\section{References}

Agence Universitaire de la Francophonie (2016). Rapport d'activite. Retrieved : https://www.auf.org/wp-content/uploads/2017/04/rapport-2016-PAP.pdf.

CNC (2016). La production cinématographique en 2016. Retrieved : http://www.cnc.fr/web/fr/publications/-/ressources/11588685.

Grin, F., Sfreddo, C. \& Vaillancourt, F. (2010). The economics of the Multilingual workplace. Abingdon, OX: Routledge - Taylor \& Francis Group.

Grin, F. (2013). The Economics of the Multilingual Workplace. London: Routledge Publishing.

Institute de la Statistique du Quebec (2016). Optique culture 2016. Retrieved : http://www.stat.gouv.qc.ca/statistiques/culture/bulletins/optique-culture-56.pdf.

International Monetary Fund (2016). Direction of Statistics Yearbook 2016. Washington: International Monetary Fund Publications.

International Organisation of La Francophonie (2015). La langue française dans le monde 2015. Retrieved : https://www.francophonie.org/La-langue-francaise-dans-lemonde.html.

International Organisation of La Francophonie (2016). Estimation des Francophones. Retrieved : https://www.francophonie.org/Estimation-des-francophones.html.

International Organisation of la Francophonie (2016). La francophonie des solutions 2016Rapport de la Secrétaire Générale de la Francophonie. Retrieved : https://www.francophonie.org/IMG/pdf/oif_rapportsg_2016-ok-web.pdf.

International Organisation of La Francophonie (2016). Profil culturel des pays du sud membres de la Francophonie- Un aperçu de trois pays de l'UEMOA. Retrieved: https://www.francophonie.org/IMG/pdf/Profil_OIF_UEMOA_vlegere.pdf.

Observatoire européen de l'audiovisuel (2016). Annuaire 2016 - Tendances clé. Strasbourg: European Audiovisual Observatory Publishing.

Office québécois de la langue française (2016). Langue publique au Quebec en 2016. Retrieved :https://www.oqlf.gouv.qc.ca/ressources/sociolinguistique/2017/20171 123_etudelanguepublique-travail.pdf.

United Nations Conference on Trade and Development (2016). Creative Economy Report 2016. Retrieved: http://unctad.org/en/PublicationsLibrary/tdstat41_en.pdf.

Vigouroux, C. (2013). Francophonie. Annual Review of Anthropology. 42, 379-397. 